\title{
Tourism in Bangladesh: Present Status and Future Prospects
}

\author{
Sanjay Chandra Roy \\ Lecturer, Department of Economics, University of Chittagong, Chittagong-4331, Bangladesh. \\ Mallika Roy \\ Lecturer, Department of Economics, University of Chittagong, Bangladesh.
}

\begin{abstract}
Bangladesh is full of natural beauty. It is surrounded by river, coasts and beaches, archaeological sites, religious places, hills, forest, waterfalls, tea gardens etc. The sundarban, Historic mosque city of Bagerhat, Ruins of the Buddihist vihara at paharpur are the three world heritage sites existed in Bangladesh among 1007. To observe the beauty of nature, huge amount of domestic and foreign tourists visit the said places. In 2012, around six lakh tourist came Bangladesh to visit and enjoy it's natural beauty. The total contribution of travel and tourism to GDP was $4.4 \%$, to employment was $3.8 \%$ and to investment was $1.5 \%$ in 2013. Bangladesh Parjatan Corporation (BPC) look after the tourism sector in Bangladesh under the ministry of Civil Aviation and Tourism. Due to some limitations, Bangladesh has failed to introduce to the tourists as a tourist destination country. The paper tries to focus on the attractive tourist spot of Bangladesh and the contribution of tourism in the Bangladesh economy. The major concern of the writer is to highlight the factors by which Bangladesh can be one of the major tourist attractive country in the world in near future.
\end{abstract}

Keywords: Tourism, Economy, Impact.

\section{Introduction \\ Concept of tourism}

Tourism is a travel for recreation, religious, leisure, family or business purposes usually for a limited duration. Tourism can be domestic or international. Now a days , tourism is one of the major source of income for many countries like Nepal.

The definition of tourism varies source by source, person by person. There is no consensus concerning the definition of tourism. Tourism was first defined by Guyer Feulerin 1905.In order to prevent the disaccords to define "Tourism", UNWTO defined it as indicated below: "Tourism comprises the activities of persons traveling and staying in places outside their usual environment for not more than one consecutive year for leisure, business and other purposes. "

Tourism is different from travel. All travel is not tourism. In order for tourism to happen, there must be a displacement. Three criteria are used simultaneously in order to characterize a travel as belonging to tourism:

Criteria-1: it involves a displacement outside the usual environment;

Criteria-2: the travel must occur for any purpose; and

Criteria-3: only a maximal duration is mentioned, not a minimal. Tourism displacement can be with or without an overnight stay.

\section{Nature of tourism}

Tourism is a service industry. It has become a very complex activity encompassing a wide range of relationships. Resulting in the improvements in standard of living and disposable income with more leisure time, the overall numbers of tourists are expected to grow further. Factors like convenient transport, no restrictions on travel, availability of information on various tourist spot and new marketing techniques contributed the growth of overall number of tourists in the present world. Additionally, a number of socio-demographic factors such as higher educational standards, advancement in information technology, rapid urbanization have strongly influenced the growth of tourism.

\section{Importance of tourism}

Tourism is an important driver of economic growth. Besides this,

People have an opportunity to exchange culture.

Tourism can earn huge amount of foreign currency.

Tourism can support the Balance of Payment (BOP) of a country.

Tourism can create employment.

\section{Impact of Tourism}

Tourism can bring many economic, social and environmental benefits, particularly in rural areas and developing countries, but mass tourism is also associated with negative effects. Tourism can only be sustainable if it is 
carefully managed so that probable negative effects on the host community and the environment are not permitted to outweigh the financial benefits.

The key benefits of tourism are economic, socio-cultural and environmental.

i) Economic benefits: Tourism can provide direct jobs to the community, such as tour guides and hotel housekeeping. Indirect employment is generated through other industries like agriculture, food production and retail. Infrastructure development and visitors' expenditure generates income for the local community and can lead to the alleviation of poverty.

ii) Social benefit: In addition to the revenue, Tourism can bring about a real sense of pride and identity to communities. It allows them to look at their history, and community identity. This helps the local residents to maintain their traditions and culture.

iii) Environmental benefit: Tourism provides financial support for the conservation of ecosystems and natural resource management, making the destination more authentic and desirable to visitors.

Negative effects of tourism are not ignorable. These are:

i) Negative economic effects: Jobs created by tourism are often seasonal and poorly paid, yet tourism can push up local property prices and the cost of goods and services. Place of tourism can be affected by terrorism.

ii) Negative social effects: Visitor behavior can have a detrimental effect on the quality of life of the host community. For example, crowding and congestion, drugs and alcohol problems can occur. Interaction with tourists can also lead to an erosion of traditional cultures and values.

iii) Negative environmental effects: Tourism poses a threat to a region's natural and cultura resources, through overuse.

\section{Objectives}

1. To know about the current status and future prospects of tourism sector in Bangladesh.

2. To identify the major tourist spots in Bangladesh.

3. To assess the contribution of tourism sector in the Bangladesh economy.

4. To identify the barriers for developing tourism sector in Bangladesh.

5. To provide some suggestions for the improvements of tourism sector in Bangladesh.

\section{Types of tourism}

The type of tourism depends on the reason for travel. Travel can be to destinations that are domestic or international. Domestic tourism involves residents travelling only within their country. International tourism may be inbound or outbound. Inbound tourism involves non-residents travelling within a country. Outbound tourism involves residents travelling within another country.

Based on the purpose of visit, tourism is categorized into the following:

\section{i) Leisure Tourism}

Tourists may travel to experience a change in climate and place and learn something new about the culture of a destination. Tourists, who seek break from the stress of day to day life, devote their holiday to rest, relaxation and refresh themselves. These tourists prefer to stay in some quiet and relaxed destination preferably at a hill resort, beach resort or island resort.

\section{ii) Cultural tourism}

Culture is most important factors which attract tourists to a destination.

Cultural tourism gives insight to

- Way of life of the people of distant land

- Dress, jewellery, dance, music, architecture

- Customs and traditions

- Fairs and festivals

\section{iv) Religious tourism}

It is a form of tourism, where people travel individually or in groups for pilgrimage. Modern religious tourists are more able to visit holy cities and holy sites around the world.

\section{iv)Family Tourism}

Family tourism involves the family unit and their participation in diverse forms of tourism activity. This includes visiting one's relatives and friends for interpersonal reasons.

\section{v) Health Tourism}

Health tourism is also called as Medical tourism. Today, many people travel great distances to exotic locations in search of medical treatment. Medical tourism is an age-old concept that has gained popularity in the recent times. Many developing countries are emerging as hot medical tourism destinations capitalizing on low cost advantages. Many hospitals have specially designed packages including resorts facilities. 


\section{vi) Sports Tourism}

Sports Tourism refers to travel which involves either viewing or participating in a sporting event staying apart from their usual environment. Normally these kinds of events are the motivators that attract visitors to visit the events like Olympic Games, FIFA World Cup etc.

\section{vii) Educational Tourism}

Educational tourism developed, because of the growing popularity of teaching and learning of knowledge and the enhancing of technical competency outside of the classroom environment. In educational tourism, the main focus of the tour visiting another country to learn about the culture, such as in Student Exchange Programs and Study Tours, organizing specialized lectures of the eminent personalities and for research.

\section{viii) Business Tourism}

Tourists visit a particular destination for various reasons pertaining to his work such as attending a business meeting, conferences, conventions selling products, meeting with clients. Business tourism is popularly called as MICE (Meetings, incentives, conferences, and exhibitions) tourism.

\section{Bangladesh at a glance and its tourism policy}

Situated between Burma and India, with the Bay of Bengal in the South, is the small country of Bangladesh. It gained independence from Britain in 1947, becoming East Pakistan. On 16 th December, 1971, Bangladesh achieved its sovereign independence, under the leadership of Bangabondhu Sheik Mujibur Rahman, after a bloody liberation war against the Pakistani Army from $26^{\text {th }}$ March in the same year.The official and main language is Bangla, but there are many small tribal language groups. Dhaka is the capital. Dhaka, Chittagong, Khulna, Rajshahi, Sylhet, Barisal and Rongpur are the major cities. Bangladesh is mainly an agriculture based country .

\section{Institutions of tourism management in Bangladesh}

Bangladesh Parjatan Corporation (BPC): BPC is an autonomous body under the ministry of Civil Aviation and Tourism established in 1972. Basic target of BPC is to expand the tourism sector and provide the service of local and foreign tourist.

National Hotel and Tourism Training Institute(NHTTI): Professional training leads to efficient management. NHTTI was established in 1974 under Bangladesh Parjatan Corporation. This institute offers such kind of courses which ensure trained personnel for Hotel and Tourism industry. NHTTI started a two year long diploma in Hotel management course in 1994. The institute also provides the job training for BPC personnel and arrange special seminar, workshop related to tourism development.

Bangladesh Tourism Board: Bangladesh Tourism Board established in 2010 to meet the strong demand for private sector and the tourism professionals. It is affiliated with United Nations World Tourism Organizations (UNWTO).

\section{Objectives of tourism policy- 2009}

1) To construct various rules under the law where the main objective is to fill in the gap of existing tourism rules and let regulations proceed.

2) To develop Tourism Industries through various planning related activities and side by side give advice as well as directions.

3) To create general awareness regarding tourism protection, development and exploration.

4) To execute responsible tourism through creation of some helping hand on behalf of government like as personal sector, local people, local admin, NGO, women federation, media.

5) To create better communication channel for the International Tourists Organizations in Bangladesh with both government and private tourism related organizations.

6) To create a strong and safe foothold for the Bangladeshi Tourist by coordinating with respective government organizations.

7) To create a tourism friendly environment in Bangladesh and to market its tourism potential in both domestic and foreign nations.

8) To develop human resource for tourism sector by creating training facilities and to provide them with the right directions.

9) To attract tourists by maintaining quality and relevant material which in turn can provide smooth tourism service and ensuring necessary actions that need to be taken for maintenance.

10) To ensure the participation of physically challenged people.

11) To protect women rights and ensure their participation in the tourism sector.

12) To research on tourism industry, to survey international markets and to analyze the data. 


\section{Tourist spots in Bangladesh}

Tourist spots in Bangladesh are not concentrated in any particular place. Instead, they are scattered throughout the country. Division wise we can present the tourist spot in Bangladesh like below:

\begin{tabular}{|l|l|l|}
\hline \multicolumn{1}{|c|}{$\begin{array}{c}\text { Name of the } \\
\text { division }\end{array}$} & \multicolumn{1}{|c|}{$\begin{array}{c}\text { Location in } \\
\text { Bangladesh }\end{array}$} & \multicolumn{1}{|c|}{ Places to visit } \\
\hline Barisal & Southwest & Kuakata \\
\hline Chittagong & Southern & $\begin{array}{l}\text { Patenga Sea Beaches, War Cemetery, Port Cox's Bazar,St. Martins Island, } \\
\text { Himchori and Inani Beach, Parki beach, Lalmai Moinamoti and Shalbon } \\
\text { Bihar, Chittagong Hill tracks(Rangamati, Khagrachari, Bandarban and } \\
\text { Kaptai ) }\end{array}$ \\
\hline Dhaka & Capital city & $\begin{array}{l}\text { Shaheed Minar, Jatiyo Smriti Soudho, Ahsan Manzil, Lalbagh Fort, Jatiya } \\
\text { Sangshad Bahavan }\end{array}$ \\
\hline Khulna & Southwest & Sundarban \\
\hline Rajshahi & Northern & Mahasthangarh, Varendra Museum \\
\hline Rangpur & Northern & 'Kantanagar Temple, Sayedpur railway junction \\
\hline Sylhet & Notrheast & $\begin{array}{l}\text { Jaflong, Ratargul, Madhabkunda waterfall, Satchari National Park } \\
\text {,Bisanakandi, Srimongal, Lawacherra Rain Forest }\end{array}$ \\
\hline
\end{tabular}

Jaflong: Jaflong is one of the best natural tourist spot in Sylhet. It is situated at the border between Bangladesh and the Indian state of Meghalaya. It is takes two hours drive to reach there. Tourist can learn something from the lifestyle of Tribe Khasia in Jaflong.

Ratargul: Ratargul is a fresh water swamp forest situated in Sylhet by the river of Goain. The water comes here from the adjacent Goain River. The flavor of Amazon forest is available there.

Madhabkunda waterfall: This is one of the largest waterfalls in Bangladesh. It is situated in Moulvibazar District. On the way visitors can see the greenish beauty of tea garden and the hills. Rubber and lemon plantations form a beautiful landscape.

Satchari National Park : This park is in Habiganj District. Wildlife in this park is rich.

Bisanakandi: Bisanakandi is situated at Bangladesh-India border in Sylhet. It is a landscape beauty among gardens and hills. Winter is not a suitable time to visit Bisnakandi due to mechanised mining and stone-laden boats and lorries.

Srimongal: Srimongal is famous for the largest tea gardens of world. Most of the tea estates are in Srimongal. It is called "The land of two leaves and a bud". It is known as the tea capital in Bangladesh. Bangladesh Tea Research Institute (BTRI) and tea museum are functioning there.

Lawacherra Rain Forest: Well-reserved forests in Bangladesh. Prime attraction of this forest is rare Chloroform tree of Asia. forest and so far from town. It is like "A Piece of Paradise".

Patenga Sea Beaches: It is about $22 \mathrm{~km}$. from Chittagong city. Besides the sea beach, you can enjoy boating and river cruise in the River Karnaphuli.

Port Area: This is the principal seaport of Bangladesh.

Cox's Bazar: World longest (120 km long) beach .Winter is the season to visit the Cox's Bazar.

St. Martins Island: St. Martins Island is the most beautiful Coral Island.

Himchori : Himchori is famous for waterfall. Visitor can reach there by jeep from Cox's Bazar.

Parki beach: It is situated in Anwara thana under southern Chittagong region.

Lalmai Moinamoti and Shalbon Bihar: They are famous historical and archeological places around Comilla city.

Rangamati: If you don't visit Rangamati you will unable to discover a big portion of natural beauties of Bangladesh.

Khagrachari: Khagrachhari is the natural wild beauty of Bangladesh. Here visitor can visit the tribal lifestyle.

Kaptai Lake: Built in early sixties Kaptai Dam and the lake are the main attractions of Kaptai.

Bandarban: Chimbuk hill is one of the major attractions of Bandarban.

Lalbagh Fort: Lalbagh Fort is an incomplete 17th century Mughal fort complex in Dhaka

Ahsan Manzil: Ahsan Manzil was a residential palace for Dhaka Nawab Famil.

Shaheed Minar: The Shaheed Minar is a national monument in Dhaka,

Jatiyo Smriti Soudho: Jatiyo Sriti Shoudho is the symbol in the memory of sacrifice of all those who gave their lives in the Bangladesh Liberation War of 1971.

Jatiya Sangshad Bahavan: It has been used for the Bangladesh National Assembly.

Sundarban: The Sundarbans is the world largest tidal mangrove forest. The Sundarbans covers approximately 10,000 square kilometres of which 60 percent is in Bangladesh with the remainder in India. The Sundarbans is a UNESCO World Heritage Site. 
Kuakata: Kuakata is a panoramic sea beach located in the Patuakhali district. Kuakata has a wide sandy beach from where one can see both the sunrise and sunset.

\section{Literature Review}

Bangladesh govt. reformed the national tourism policy in 2010. Aims and goals of this policy is to increase employment, ensure economic development, environmental purity and sustainability ( S.M. SIRAJ). The major objective of the policy is to develop Eco-tourism through conservation of natural resources and promote wellbeing of the community, preservation of cultural values of the local community and their participation and sharing benefits. Govt. of Bangladesh launched an act of " Protected areas of tourism and special tourism zone act 2010"( Akhtaruzzaman Khan Kabir). Bangladesh is the country in the region that have the least arrivals and revenue earned from tourism industry( Majbritt Thomsen). Tourism is one of the profitable sectors in Bangladesh( Md Lutfur Rahman, S N Nawshad Hossain, Sania Sifiat Miti, Dr. AKM Abul Kalan). Tourism sector of Bangladesh is facing many obstacles in its sustainable(ARIF, ISLAM-2011). In this current study data from several secondary international sources have been used to analyze the pattern of tourism in Bangladesh. Policy recommendations have also been provided based on this analysis.

\section{Methodology and Data Analysis:}

The study is based on secondary data. The data have been collected from different reports , published article, Websites, Bangladesh Parjatan Corporation (BPC), Ministry of Civil Aviation and Tourism, World Travel and Tourism Council( WTTC), Bangladesh Bureau of Statistics(BBS), Daily newspapers etc. Analysis is based on various statistical techniques.

\section{Present status of tourism in Bangladesh}

The importance of tourism sector has increased overtime. In 2009-2010, 838 lakh taka was allocated for tourism sector in national budget. This has been increased to 1818 lakh taka in 2011-2012. But of late there is a decreasing trend in tourism expenditure. In 2013-2014, tourism expenditure in national budget has been falling to 683 lakh taka. This decreasing trend may be due to the current political crisis which has discouraged in our tourism in Bangladesh.

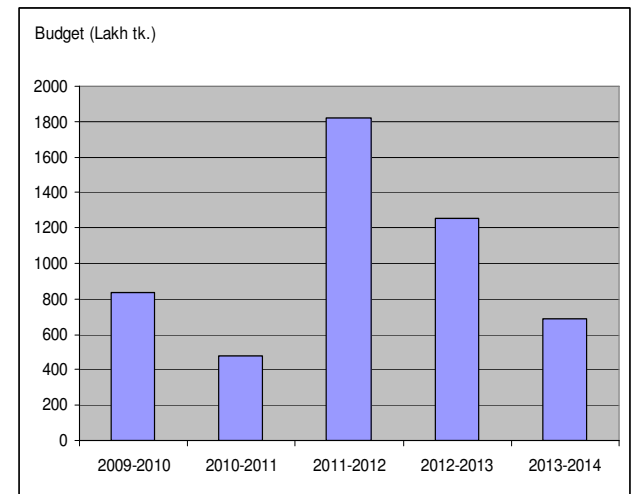

Figure 1: Distribution of money at the tourism sector in the national budget Source: Bangladesh Parjatan Corporation

Table 1: Income, expenditure and profit of Bangladesh parjatan corporation in the last five years

\begin{tabular}{|c|c|c|c|}
\hline Fiscal Year & $\begin{array}{c}\text { Total income } \\
\text { (Lakh tk. })\end{array}$ & $\begin{array}{c}\text { Total expenditure } \\
\text { (Lakh tk. })\end{array}$ & $\begin{array}{c}\text { Profit before } \\
\text { tax(Lakh tk. })\end{array}$ \\
\hline $2008-2009$ & 3598.60 & 3792.35 & -193.75 \\
\hline $2009-2010$ & 4535.88 & 4512.47 & 23.41 \\
\hline $2010-2011$ & 5966.71 & 5819.21 & 107.50 \\
\hline $2011-2012$ & 7127.82 & 6836.62 & 291.20 \\
\hline $2012-2013$ & 7168.33 & 6556.00 & 612.33 \\
\hline
\end{tabular}
Table- 1

Source: Bangladesh Parjatan Corporation( 2014)

In Bangladesh, govt. controlled tourism organization, Bangladesh Parjatan Corporation (BPC) is doing well in terms of profit. In 2008-2009 it made a loss of about 194 lakh taka. But since then it is making profit. In 20092010 the profit was 23.41 lakh taka which has consistently increased to 612.33 lakh taka in 2012-2013. This profit has accompanied by both increasing total income and total expenditure. This total income and total expenditure in 2008-2009 were 3598.6 and 3792.35 lakh taka respectively. These figures have risen to 7168.33 and 6556 lakh taka respectively in 2012-2013. 
The number of tourist that came into Bangladesh during 2008 to 2012 are show in Figure 2:

The inbound tourism severely fall to 2,67,107 in 2009 from the previous year 4,67,332. This may be due to the global financial crisis. The number of tourist, however, show increasing trend after 2009. The inbound tourism recovered to 3,03,386 in 2010 and has increased to 5,88,193 in 2012.

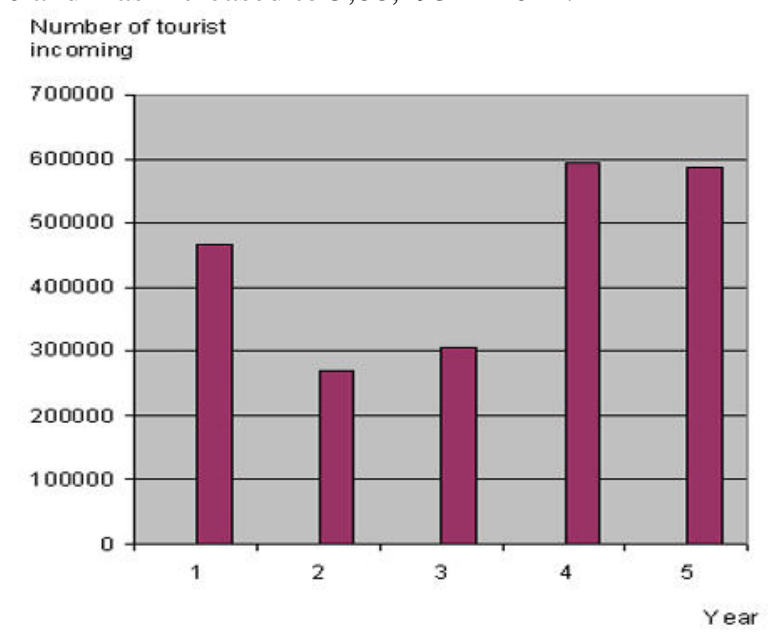

Figure 2: Statistics of tourist incoming in Bangladesh

Contribution of tourism in the Bangladesh economy

Source: Bangladesh Parjatan Corporation ( 2014)

Figure 3: Contribution of travel \& tourism to GDP

According to World Travel \& Tourism Council (WTTC) report (2014), The total contribution of travel and tourism was $4.4 \%$ of GDP in 2013 and is expected to grow $7.9 \%$ to $4.5 \%$ of GDP in 2014. It is forecasted to rise by $6.5 \%$ per annum to $4.7 \%$ of GDP by 2024 . Notable that, total contribution consists of direct, indirect and induced contribution.

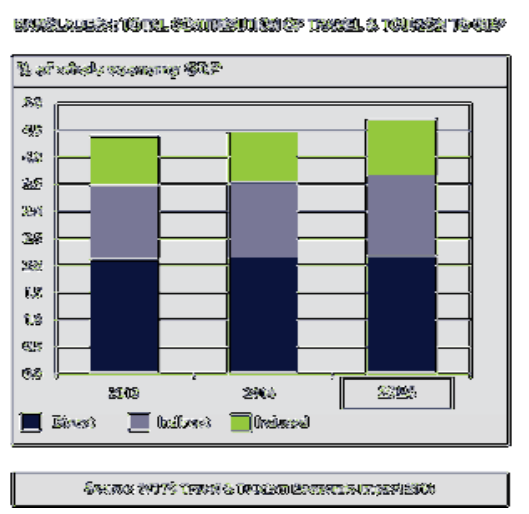

Figure: 3

Figure 4: Contribution of travel and tourism to employment generation

Travel and Tourism generated 1,328,500 jobs directly in 2013 and this is forecasted to grow by $4.0 \%$ in 2014 . This includes employment by hotels, airlines, travel agents and other passenger transportation services. It will increase by $2.7 \%$ per annum on average over the next ten years.

The total contribution of Travel and Tourism to employment was $2.8 \%$ of total employment in 2013. This is forecasted to rise to $3.9 \%$ of total employment in 2014. By 2024, travel and tourism are forecasted to support $4.2 \%$ of total employment . 


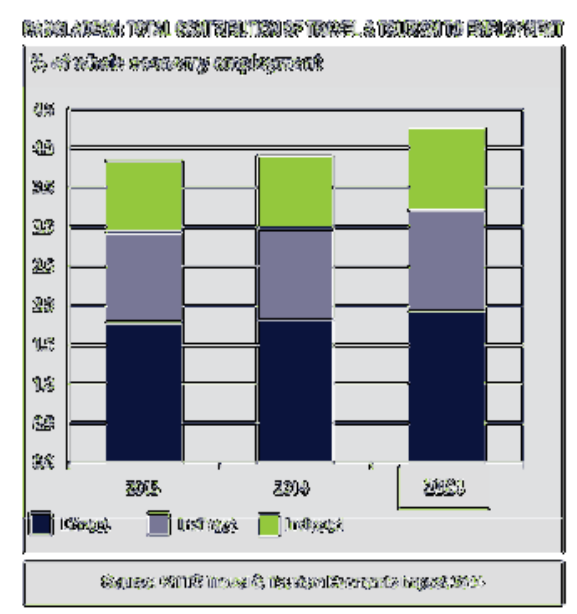

Figure: 4

\section{Figure 5: Contribution of travel and tourism to Visitor Exports}

Visitor exports are a key component of the direct contribution of travel and tourism .Visitor spend a good sum of money during their stay in the country. Spending on food, travels, and hotel are included in the visitor exports category. In 2013, Bangladesh generated BDT8.3 billion in visitor exports. In 2014, this is expected to grow by 7.1\%. By 2024, international tourist arrivals are forecasted to 611,000 generating expenditure of BDT15.5 billion.

Travel and Tourism's contribution to total national investment will rise from 1.5\% in 2014 to $1.6 \%$ in 2024.

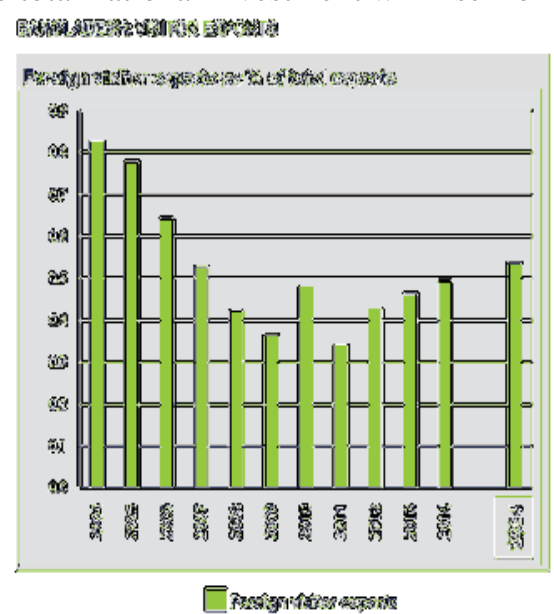

Figure: 5

\section{Conclusion and Recommendations}

Now Bangladesh is low-middle income country. It's average GDP growth rate is $6 \%$. The economy is highly dependent on Manpower export, Ready Made Garments(RMG), and Agriculture sector. Other prominent sectors are Shipbuilding, Pharmaceuticals etc. The rate of employment is $90 \%$, which is below expected level. As a result, disguised employment and employment at low wage rate rising. Many of them are illegally crossing border in the hope of better life. For the improvement of employment rate, to stop the illegal migration or to receive the social, cultural and economic benefits of the tourism sector govt. has to take and implement some projects and policies. As part of tourism sector development, recently govt. pass the Cox's Bazaar Development Authority (CDA) at the meeting of ministry. This is supportable but not enough. The govt. of Bangladesh should place equal emphasis in its policy on the development of the tourist spots all over the country. This will create employment opportunity on the one hand and on the other hand reduce the dependence of the country on some other specific sectors.

Following measures are necessary for the development of tourism sector in Bangladesh

1.Up-date the present tourism policies in Bangladesh compare to the world tourism market.

2. Tourism spot and related organization should run by the private sector.

3. Tourism related discipline like hotel and tourism management should be start at the all university in Bangladesh. 
4. Infrastructures around the tourism sector should be built and maintained . Rail connection between Cox's Bazaar and Chittagong is necessary. Because, present communication system is not enough for tourist attraction.

5. Political stability should be maintained to attract the foreign tourist.

6. Govt. should take the actions about the security system at the tourist place

\section{References}

ARIF \& ISLAM (2011): Opportunities of tourism in Bangladesh: Volume No. 1, Issue No.6 INTERNATIONAL JOURNAL OF RESEARCH IN COMMERCE, IT AND MANAGEMENT

Daily Newspaper of Bangladesh: The Daily Star, The Prothom-alo.

Kabir: Global sustainable tourism criteria: Perspective Bangladesh.

Rahman, Hossain, Miti \& Kalam: An review of present status and future prospects of the tourism sector in Bangladesh

SIRAJ:Review of tourism policy in Bangladesh, scope for future improvements.

Thomsen: Introduction to the tourism industry in Bangladesh.

World Travel \& Tourism Council (WTTC): Annual report-2014: The Economic Impact of Travel \& Tourism 2014.

www.bangladeshtourism.gov.bd : Bangladesh Parjatan Corporation (BPC).

www.tourismboard.gov.bd: Tourism Policy- Bangladesh Tourism Board (National Tourism Organization). 
The IISTE is a pioneer in the Open-Access hosting service and academic event management. The aim of the firm is Accelerating Global Knowledge Sharing.

More information about the firm can be found on the homepage:

http://www.iiste.org

\section{CALL FOR JOURNAL PAPERS}

There are more than 30 peer-reviewed academic journals hosted under the hosting platform.

Prospective authors of journals can find the submission instruction on the following page: http://www.iiste.org/journals/ All the journals articles are available online to the readers all over the world without financial, legal, or technical barriers other than those inseparable from gaining access to the internet itself. Paper version of the journals is also available upon request of readers and authors.

\section{MORE RESOURCES}

Book publication information: http://www.iiste.org/book/

Academic conference: http://www.iiste.org/conference/upcoming-conferences-call-for-paper/

\section{IISTE Knowledge Sharing Partners}

EBSCO, Index Copernicus, Ulrich's Periodicals Directory, JournalTOCS, PKP Open Archives Harvester, Bielefeld Academic Search Engine, Elektronische Zeitschriftenbibliothek EZB, Open J-Gate, OCLC WorldCat, Universe Digtial Library, NewJour, Google Scholar

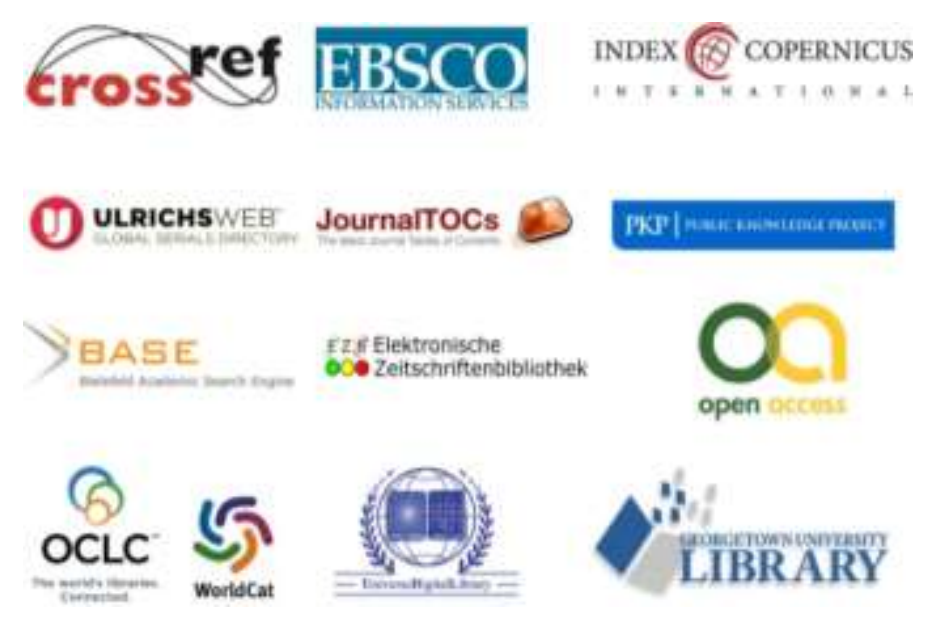

